\title{
Analyzing the Effective Factors on Customer Behavior in Mobile Marketing
}

\author{
Tahereh Arbab \\ Department of IT, Electronic Branch, \\ Islamic Azad University, \\ Tehran, IRAN \\ tahereh.arbab@gmail.com
}

\author{
Hojatolah Hamaidi Professor in \\ Industries-Information Technology, \\ Academic Staff and Assistant \\ Professor, Khaje Nasiratooi University \\ h_hamid@kntu.ir
}

\author{
Mohsen Gharakhani \\ Professor in Industries-Industries, \\ Financial Engineering, Academic \\ Board and Assistant Professor at \\ Qom University \\ m.gharakhanian@qom.ac.ir
}

\begin{abstract}
Nowadays, customers play a very important and vital role in the field of global economy. As a result, companies give special significance to the customers to survive and grow in the field of economic competition in the modern world and increase their relationship with the buyers of their products and services throughout their lifetime. Marketing growth through mobile phones has provided further motives for performing more researches in the field of customer behavior and attitude in mobile marketing. The goal of the current study is to analyze the effective factors on customer behavior in mobile marketing. The variables used in this study are perceived ease of use, individual knowledge, user's mobile phone technology, customers' negative attitudes, and customers' positive attitudes. The current research is practical in terms of objective and is descriptive-analytic in terms of methodology. Data were gathered by distributing a questionnaire among 284 students of Tehran University. Data were analyzed by structural equation modeling using Lisrel and Expert Choice software. Test results showed that ease of use, individual knowledge, mobile phone technology, positive attitude, and negative attitude variables have a meaningful effect on customer behavior in mobile marketing. The confirmation of all the assumptions of the research supports the importance of the customer behavior analysis in mobile phone services.
\end{abstract}

Keywords-Mobile marketing; Customer Behavior; Structural Equations; Decision Making; Individual Knowledge

\section{INTRODUCTION}

Currently, the commercial interface between the customers and companies is very important. Customer Relationship Management (CRM) that is considered to manage customer relationship deals with such a relationship. The function of the $\mathrm{mCRM}$ is to support customers and personnel through Information Technology (IT) in the field of mobile phone commerce [16]. The services related to mobile communication can be called a miracle because mobile devices have penetrated all aspects of human life and can help human talent. However, in the case of desktop customers, it is related to applications $[1,8]$ and provides wonderful features and opportunities for desktop users [3]. The environment of the company is studied during development, then, goals are determined and an agenda is designed that in which a plan is presented for products. The usual mobile phones are accessible to all community members. Mobile phone devices have appeared as a new business and converted into a highpotential market. With the emersion of wireless technologies with high speed, mobile phones became very popular among commercial and non-commercial companies due to their high influence and inherent features. The global mobile phone advertising market is growing and has reached more than 100 billion dollars. The mobile phones were created through development processes with the aim of providing free communication regardless of the current location of users. In addition, it should be noted that Martin Cooper registered the first mobile phone on April 3, 1973, in
New York. This invention accelerated communication among the community members and eliminated all spatial and temporal limitations of traditional phones. With the emersion of the wireless network technologies with high speed, the main features of this technology increased the penetration and popularity of using mobile phones in marketing for commercial and noncommercial applications [12]. Since the influence on mobile marketing has been facilitated significantly, the global business takes the best advantage of mobile marketing [14]. In [4] authors studied the existing knowledge about mobile marketing and its importance for consumers and retailers. When smartphones emerged, a torrent of demand was raised in the field of mobile marketing.

The developed model in this article attempts to study the behavioral consequences of customers and accepting ads through mobile phones. Therefore, this study can be used to develop strategies in business and analyze mobile marketing in terms of its performance.

\section{THEORETICAL PRINCIPLES}

\section{A. Mobile marketing background}

In the first place, internet marketing appeared, then, mobile marketing emerged as a new tool to marketing and its goal was to find customers through active networks in mobile phones. This kind of marketing is introduced and classified as system marketing. Mobile phones have created a new interesting channel for marketing activities that can provide the possibility to make effective connections with target markets by 
creating two-way connections between marketer and customers. According to Deiler, the goals of managing customers based on mobile phones can be divided into five general and key groups-functional goals, interactive goals, customer goals, market goals, and income goals. However, the properties of traditional shopping have different nature and modern shopping cannot replace traditional shopping completely.

\section{B. Mobile marketing and its importance}

According to the definition of Mobile Marketing Association (MMA), Strom et al. believe that mobile marketing provides companies with the opportunity to direct customers attention toward effective communication through mobile phones and digital personal assistants [15]. Among the various definitions of mobile marketing, [14]. offer a definition of technology where may be some mistakes in conceptualization [15]. Leppaniemi and Karjaluoto declared that the most accepted definition is the definition presented by MMA.

"Using as a market communication application or a multimedia application or as an integrated content distribution and receiving a direct response through wireless media"

However, Leppaniemi et al. presented the following definition for mobile marketing: "using the mobile phone environment as a marketing" [16].

\section{Customer behavior in mobile marketing}

The perceived ease of use is effective on customer behavior in mobile marketing. The effects of mobile marketing on customer reaction are positive. The customer feedback to a special driver is called customer response.

The consumer response has a close relationship with training and is related to past subjects as well. The researchers conducted on consumer behavior shows that consumer response to ads can be influenced by factors like information analysis, motivation, feedback, and people ideas about ads.

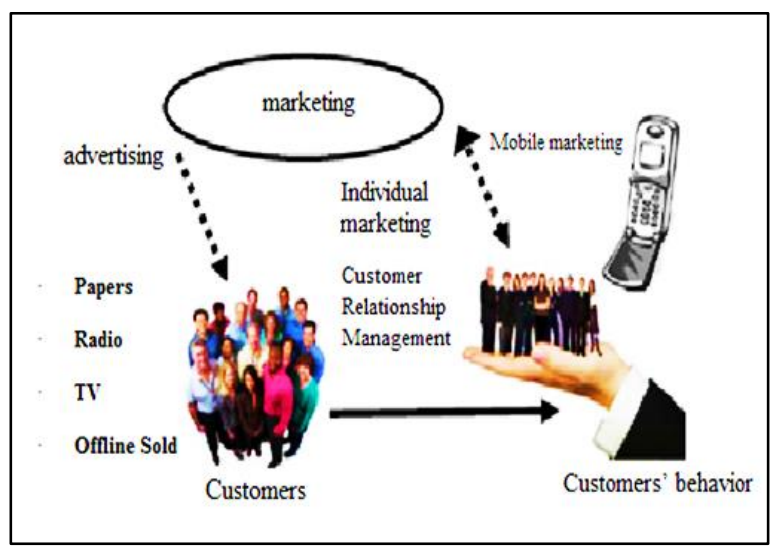

FigURE 1. MOBILE MARKETING AS A NEW TOOL IN INDIVIDUAL MARKETING.

\section{Benefits of mobile marketing}

Mobile marketing isn't considered as a single technology rather this capability of using technology leads to saving time, money, and analysis. This great revolution first emerged in Asia followed by Europe and America and reduced the mistakes and inefficiencies in marketing and advertising as much as possible. Friedrich et al. believe that with the aim of working with extensive budgets, mobile marketing hasn't been seemed necessary until now; the professional individuals of marketing need absolute trust in brand and contents [17].

\section{E. Mobile Ads}

Retailers, producers, and service providers contribute to the field of advertising by making related proposals [18]. The mobile phone facilities for advertising is a progressing and flourishing phenomenon.

Mobile phone advertising has experienced more than 19 billion dollars increase since 2014 in the USA. This figure will increase to 65 billion dollars by 2019 ; these ads will cover $75 \%$ of total digital ads [19].

The global market for mobile phone advertising is growing and has reached more than 100 billion dollars. According to statistics, more than half the digital advertising incomes in 2016 is obtained through mobile phone [6]. Mobile phone marketing has a deep effect on the global business environment [20-29]. The rapid development of wireless communication has made the influence of Mobile Internet Business very significant. In the history of technology, there isn't any phenomenon like wireless communication technology which has influenced all the aspects of human life and has made many opportunities in the E-Commerce world to individually communicate with customers. Andrews et al. propose new results regarding this problem; they believe that the effectiveness of SMS ads isn't the same at all times and is dependent on the time and receiver population rate. In fact, behavior tests can be addressed by controlled methods that accelerate other tests on physical location.

\section{F. Mobile communication technologies}

Some researchers believe that the mobile technology revolution can be seen as a development in communications. The mentioned evolution started by developing the wireless telegraph to traditional phone systems in the 1980s. Then, analog systems were converted into mobile phone devices. The mobile phone services became accessible through multi-media systems in 2000.

\section{G. Existing challenges in mobile marketing}

Mobile marketing has reached its place in terms of the budget assigned by companies but there are still some barriers which reduce the interest of users in mobile marketing and trade. These barriers are as follows. 
In particular, the small size of mobile phone screens and keyboards make searching for products and services relatively difficult [30-38].

\section{RESEARCH MODEL}

By reviewing the research background and using research assumptions, the conceptual research model was formulated as follows. It is expected that the factors indicated in figure 2 namely ease of use, individual knowledge, mobile technology, negative attitude, and positive attitude have a positive impact on customer behavior.

\section{A. Conceptual framework}

The following conceptual framework was presented to clarify the relationship, assumptions, and logic of mobile phone marketing.

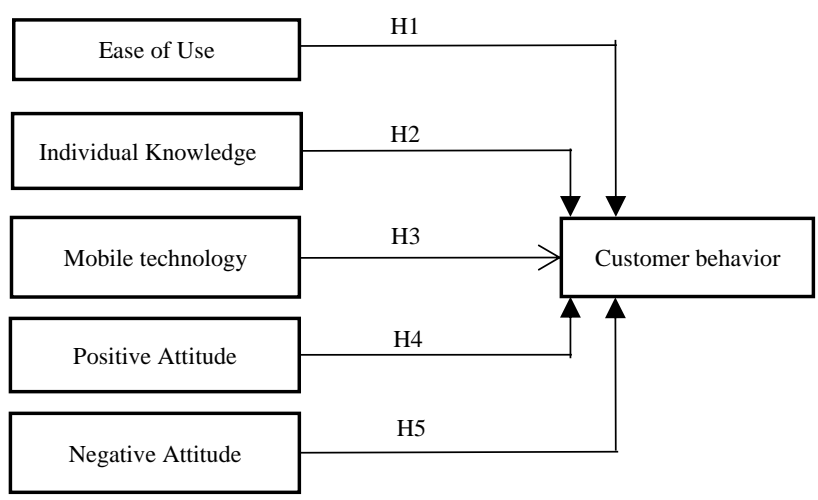

FIGURE 2. CONCEPTUAL FRAMEWORK

\section{B. Methodology}

Based on the proposed model, this study shows the interconnected factors that can impress Iranian customer behavior in using mobile phone services. According to the usages of library and field methods like questionnaire, the type of data collecting method is descriptive.

$$
n=\frac{z_{\frac{\alpha}{2}}^{2} s_{x}^{2}}{e^{2}}=\frac{(1.96)^{2}(0.25)}{(0.05)^{2}}=284
$$

\section{Where}

$n$ is the required sample number.

$e$ is sampling error.

$\alpha$ is in confidence level.

$z_{\frac{\alpha}{2}}^{2}$ is the level related to a normal distribution standard of $95 \%$.

$s_{x}^{2}$ is observed variable standard deviation (behavioral intend to use mobile marketing).
The mentioned items were used to measure the variables of previous research. This relationship has been summarized in Table 1.

TABLE I. THE RELATIONSHIP BETWEEN THE QUESTIONNAIRE - The screen size of the mobile phones isn't big enough.

- The mobile phone calls used for mobile advertising are very expensive.

- The short lifetime of batteries.

- One of the important challenges in mobile marketing through mobile phone is the variety of mobile phones and various defects of them so that users don't have enough information about them.

- The popularity of traditional shopping.

- The risk of quality decline after product delivery (compared to the advertised product).

- Intangible and indirect services.

\begin{tabular}{|c|c|}
\hline \multicolumn{2}{|r|}{ AND RESEARCH RESOURCES } \\
\hline Variables & Measurement indices \\
\hline \multirow[t]{5}{*}{ Ease of use } & $\begin{array}{l}\text { I receive updated information through } \\
\text { advertising messages of the mobile phone. }\end{array}$ \\
\hline & $\begin{array}{l}\text { I receive exclusive messages through } \\
\text { advertising messages of the mobile phone. }\end{array}$ \\
\hline & $\begin{array}{l}\text { Adverting through mobile phone will be } \\
\text { my saving costs. }\end{array}$ \\
\hline & $\begin{array}{l}\text { Advertising through mobile phone will } \\
\text { always cause time-saving. }\end{array}$ \\
\hline & I can get ads through a mobile phone. \\
\hline \multirow[t]{3}{*}{$\begin{array}{l}\text { Individual } \\
\text { knowledge }\end{array}$} & $\begin{array}{l}\text { I have enough information about the } \\
\text { capabilities of my mobile phone. }\end{array}$ \\
\hline & $\begin{array}{l}\text { I know various kinds of communication } \\
\text { methods. }\end{array}$ \\
\hline & $\begin{array}{l}\text { I can easily receive advertising messages } \\
\text { on my mobile phone. }\end{array}$ \\
\hline \multirow[t]{4}{*}{$\begin{array}{l}\text { Mobile } \\
\text { technologies }\end{array}$} & $\begin{array}{l}\text { I like advertising through receiving Multi- } \\
\text { Media Message Service (MMS). }\end{array}$ \\
\hline & $\begin{array}{l}\text { I think getting advertising through } \\
\text { Bluetooth technology is interesting. }\end{array}$ \\
\hline & $\begin{array}{l}\text { I think advertising through internet } \\
\text { technology of mobile phone (music } \\
\text { streaming, E-Mail, etc.) is entertaining. }\end{array}$ \\
\hline & $\begin{array}{l}\text { Operations in different networks of my } \\
\text { mobile phone are more interesting. }\end{array}$ \\
\hline \multirow{4}{*}{$\begin{array}{l}\text { Negative } \\
\text { attitude }\end{array}$} & Ads are always deceptive. \\
\hline & $\begin{array}{l}\text { Advertising through mobile phone is } \\
\text { annoying. }\end{array}$ \\
\hline & Ads are always confusing. \\
\hline & $\begin{array}{l}\text { The unilateral relationship in mobile } \\
\text { advertising affects me. }\end{array}$ \\
\hline $\begin{array}{l}\text { Positive } \\
\text { attitude }\end{array}$ & $\begin{array}{l}\text { Advertising through mobile phone is } \\
\text { pleasant. }\end{array}$ \\
\hline
\end{tabular}


Advertising through mobile phone is always entertaining.

Advertising through mobile phone is always delightful.

Advertising through mobile phone is useful.

I think advertising through mobile phone is a great idea.

The confidence level is measured by Cronbach's alpha in the questionnaire. The results obtained from this test are presented in the following Table.

TABLE II. CONFIDENCE LEVEL MEASUREMENT BY CRONBACH'S ALPHA IN THE QUESTIONNAIRE

\begin{tabular}{|l|l|r|r|}
\hline Variables & \multicolumn{1}{|c|}{$\begin{array}{l}\text { Number of } \\
\text { questions }\end{array}$} & $\begin{array}{c}\text { Number of } \\
\text { samples }\end{array}$ & $\begin{array}{l}\text { Cronbach's } \\
\text { alpha }\end{array}$ \\
\hline Ease of use & Q1-Q6 & 284 & 0.757 \\
\hline $\begin{array}{l}\text { Individual } \\
\text { knowledge }\end{array}$ & Q7-Q10 & 284 & 0.785 \\
\hline $\begin{array}{l}\text { Mobile } \\
\text { technology }\end{array}$ & Q11-Q17 & 284 & 0.778 \\
\hline $\begin{array}{l}\text { Negative } \\
\text { attitude }\end{array}$ & Q18-Q21 & 284 & 0.700 \\
\hline $\begin{array}{l}\text { Positive } \\
\text { Attitude }\end{array}$ & Q22-Q24 & 284 & 0.716 \\
\hline $\begin{array}{l}\text { Whole } \\
\text { questionnaire }\end{array}$ & Q25-Q26 & 284 & 0.724 \\
\hline
\end{tabular}

\section{RESUlTS}

The descriptive statistics including frequency, percentage, and characteristics of the census are presented in Table 3.

TABLE III. DESCRIPTIVE STATISTICS

\begin{tabular}{|c|c|c|c|}
\hline $\begin{array}{l}\text { Statistics } \\
\text { properties }\end{array}$ & Data & $\begin{array}{l}\text { Frequency } \\
\qquad(n=284)\end{array}$ & $\%$ \\
\hline \multirow[b]{2}{*}{ Gender } & Male & 177 & 62 \\
\hline & Female & 107 & 38 \\
\hline \multirow{6}{*}{ Age } & $\begin{array}{l}\text { Less than } \\
25 \text { years }\end{array}$ & 45 & 16 \\
\hline & $25-30$ & 65 & 23 \\
\hline & $31-35$ & 71 & 25 \\
\hline & $36-40$ & 55 & 19 \\
\hline & $41-45$ & 40 & 14 \\
\hline & $\begin{array}{l}45 \text { years } \\
\text { and over }\end{array}$ & 8 & 3 \\
\hline \multirow[t]{3}{*}{ Education } & Bachelor & 154 & 54 \\
\hline & Master & 112 & 40 \\
\hline & Ph.D. & 18 & 6 \\
\hline
\end{tabular}

\begin{tabular}{|c|c|c|c|}
\hline Using Mobile & $\begin{array}{c}\text { Less than 2 } \\
\text { hours }\end{array}$ & 63 & 22 \\
\hline $2-4$ & 97 & 34 \\
\hline $5-7$ & 112 & 40 \\
\hline $\begin{array}{c}7 \text { hours or } \\
\text { more }\end{array}$ & 12 & 4 \\
\hline
\end{tabular}

\section{A. Factors of ranking customer behavior in mobile} marketing

In the current study, the effective factors on customer behavior in mobile marketing are ease of use, individual knowledge, mobile technology, negative attitude, and positive attitude.

TABLE IV. COMPARING THE EFFECTIVE FACTORS ON CUSTOMER BEHAVIOR IN MOBILE MARKETING

\begin{tabular}{|c|c|c|c|c|c|c|}
\hline 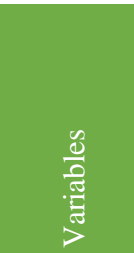 & 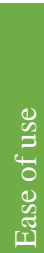 & 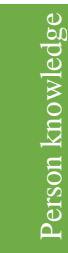 & $\begin{array}{l}\text { on } \\
0 \\
0 \\
\vdots \\
0 \\
0 \\
0 \\
\frac{0}{0} \\
\frac{0}{2}\end{array}$ & 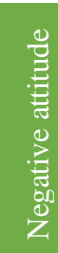 & 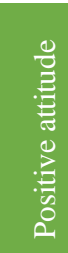 & $\begin{array}{l}\frac{0}{0} \\
\frac{0}{8} \\
0 \\
0\end{array}$ \\
\hline Ease of use & 1 & 2.33 & 1.99 & 2.14 & 2.35 & 0.219 \\
\hline $\begin{array}{l}\text { Person } \\
\text { knowledge }\end{array}$ & & 1 & 1.08 & 2.21 & 2.07 & 0.189 \\
\hline $\begin{array}{l}\text { Mobile } \\
\text { technology }\end{array}$ & & & 1 & 1.99 & 1.83 & 0.300 \\
\hline $\begin{array}{l}\text { Negative } \\
\text { attitude }\end{array}$ & & & & 1 & 1.79 & 0.156 \\
\hline Coefficient & & & & & 1 & 0.136 \\
\hline
\end{tabular}

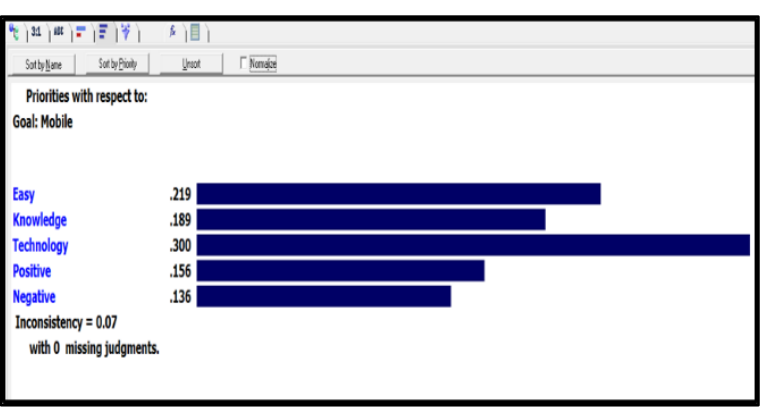

FIGURE 3. THE FACTORS OF RANKING CUSTOMER BEHAVIOR IN MOBILE MARKETING

The resulted compatibility rate is 0.07 and since this value is less than 0.10 , it is acceptable and there is no need to solve incompatibility. As a result, all five hypotheses discussed in this study are confirmed.

TABLE V. RANKING THE EFFECTIVE FACTORS ON CUSTOMER BEHAVIOR IN MOBILE MARKETING

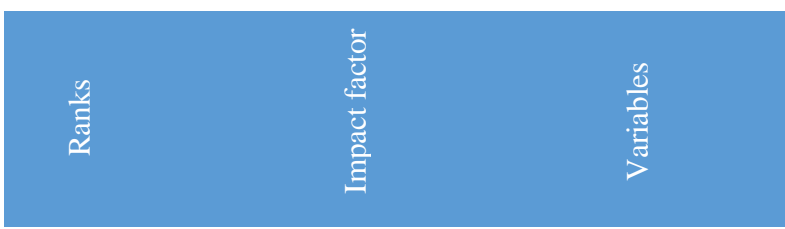




\begin{tabular}{|c|c|c|}
\hline 1 & 0.300 & $\begin{array}{c}\text { Mobile } \\
\text { technology }\end{array}$ \\
\hline 2 & 0.219 & Ease of use \\
\hline 3 & 0.189 & Person knowledge \\
\hline 4 & 0.156 & Positive attitude \\
\hline 5 & 0.136 & Negative attitude \\
\hline
\end{tabular}

\section{B. Data analysis}

In the following, the effect of the following variables on the main indices of the study (ease of use, individual knowledge, mobile technology, negative attitude, and positive attitude) are discussed.

\section{Analyzing ease of use variable}

The standardized factors (standard regression factors) of ease of use variable were estimated and 6 indices can be seen in the following chart.

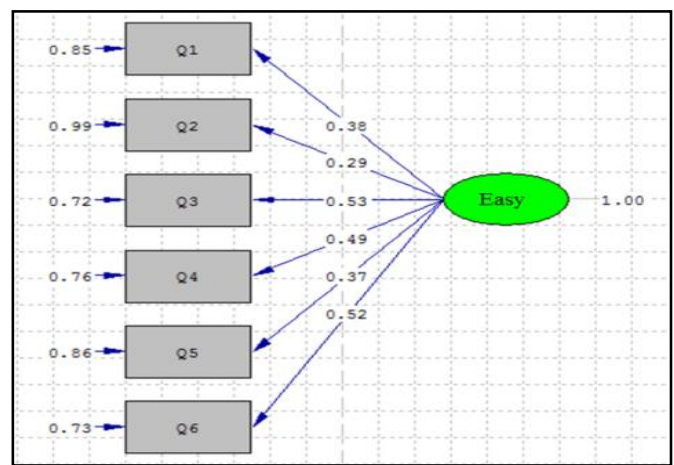

FIGURE 4. EVALUATING THE STANDARD FREQUENCY OF EASE OF USE VARIABLE

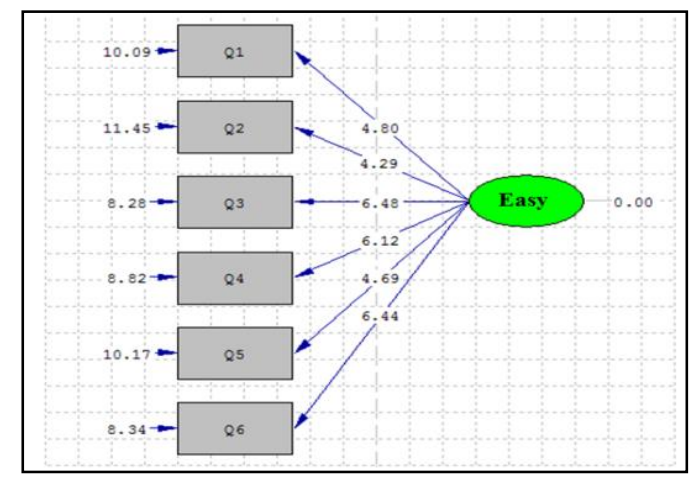

FIGURE 5. STUDENT-T TEST OF EASE OF USE VARIABLE

TABLE VI. MULTIPLE DETERMINANT FACTORS FOR EASE OF USE VARIABLE

\begin{tabular}{|c|c|c|c|c|c|c|}
\hline 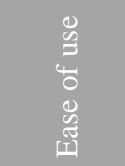 & $\begin{array}{l}\overrightarrow{\widetilde{J}} \\
\bar{\Xi} \\
\vec{\Xi}\end{array}$ & 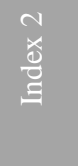 & $\begin{array}{l}m \\
\stackrel{x}{e} \\
\stackrel{\tilde{J}}{\Xi}\end{array}$ & $\begin{array}{l}\dot{J} \\
\frac{x}{d} \\
\stackrel{d}{\Xi}\end{array}$ & $\begin{array}{l}n \\
\text { ๘ } \\
\stackrel{\Xi}{\Xi} \\
\Xi\end{array}$ & $\begin{array}{l}0 \\
\times \\
\stackrel{\jmath}{0} \\
\Xi\end{array}$ \\
\hline $\begin{array}{l}\text { Multiple } \\
\text { determin } \\
\text { ant } \\
\text { factors }\end{array}$ & 0.15 & 0.13 & 0.28 & 0.24 & 0.14 & 0.27 \\
\hline
\end{tabular}

Studying the indices of the model shows the validity of the model. Therefore, the final model can properly describe the relationship between the descriptive variables. The standardized load factors (standardized regression factor) are the variable of individual knowledge and its 4 indices can be seen in the following Figure and Table.

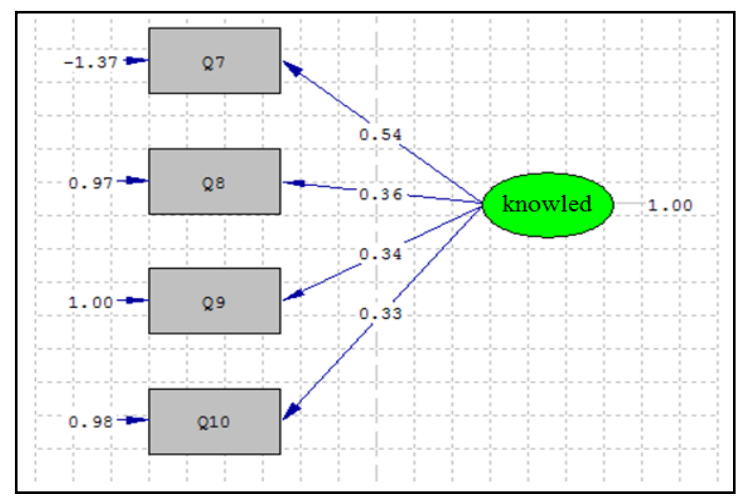

FIGURE 6. EVALUATING THE STANDARD FREQUENCY OF INDIVIDUAL KNOWLEDGE VARIABLE

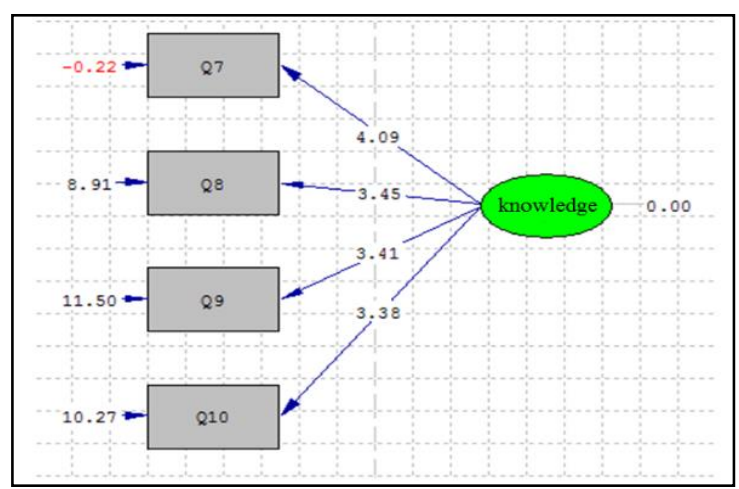

FIGURE 7. STUDENT-T TEST OF INDIVIDUAL KNOWLEDGE VARIABLE

TABLE VII. MULTIPLE DETERMINANT FACTORS FOR INDIVIDUAL KNOWLEDGE VARIABLE

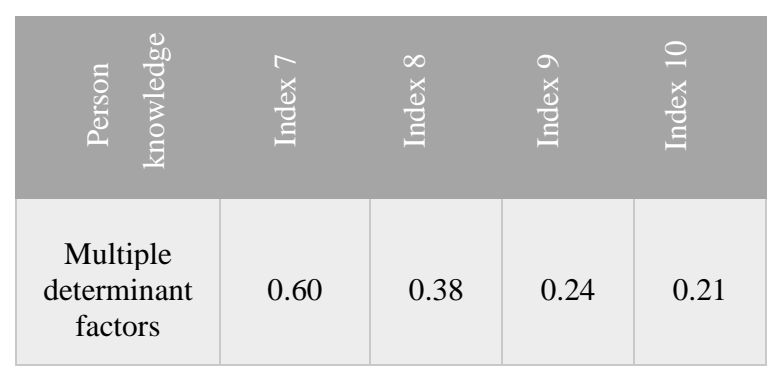

Examination of the model criteria shows that the model has good validity. Therefore, the final model can accurately describe the relationships between the descriptive variables.

\section{Analyzing mobile technology variable}

The following.

The standardized factors (standard regression factors) of mobile technology variable were estimated and 7 indices can be seen in the following chart. 


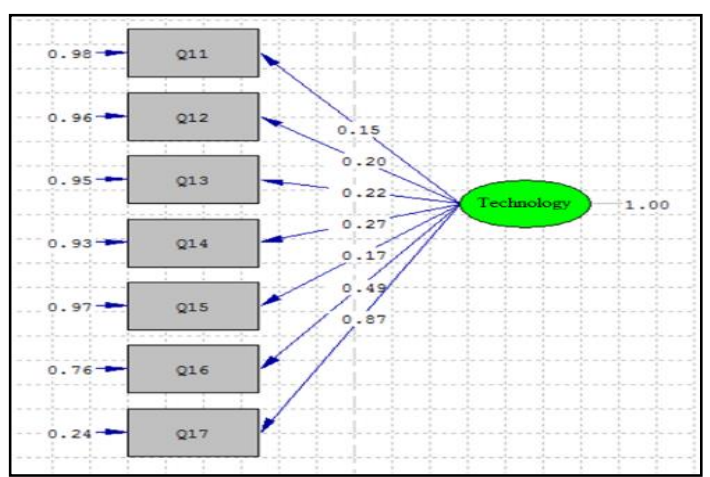

FIGURE 8. EVALUATING THE STANDARD FREQUENCY OF MOBILE TECHNOLOGY VARIABLE

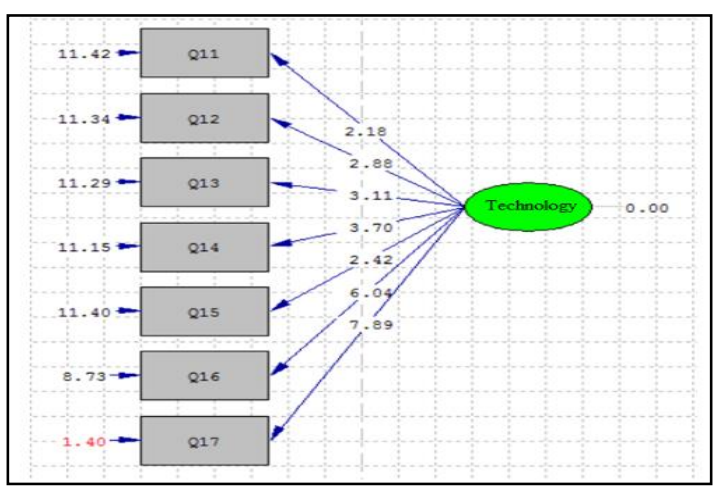

FIGURE 9. STUDENT-T TEST OF MOBILE TECHNOLOGY VARIABLE

TABLE VIII. MULTIPLE DETERMINANT FACTORS FOR MOBILE TECHNOLOGY VARIABLE

\begin{tabular}{|c|c|c|c|c|c|c|c|}
\hline $\begin{array}{c}\text { Mobile } \\
\text { technolog } \\
y\end{array}$ & $\begin{array}{l}\exists \\
\vec{x} \\
\frac{o}{g}\end{array}$ & $\begin{array}{l}\text { ป } \\
\text { ex } \\
\text { E }\end{array}$ & $\begin{array}{l}\frac{m}{a} \\
\frac{a}{0} \\
\frac{0}{\Xi}\end{array}$ & $\begin{array}{l} \pm \\
\text { ฮ } \\
\stackrel{\Xi}{\Xi}\end{array}$ & $\begin{array}{l}\frac{n}{a} \\
\frac{o}{\Xi} \\
\Xi\end{array}$ & $\begin{array}{l}0 \\
\frac{x}{0} \\
\frac{0}{E}\end{array}$ & 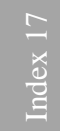 \\
\hline $\begin{array}{c}\text { Multiple } \\
\text { determin } \\
\text { ant } \\
\text { factors }\end{array}$ & 0.21 & 0.26 & 0.33 & 0.35 & 0.23 & 0.44 & 0.76 \\
\hline
\end{tabular}

Studying the indices of the model shows the validity of the model. Therefore, the final model can properly describe the relationship between the descriptive variables.

\section{E. Analyzing the negative attitude variable}

The following.

The standardized factors (standard regression factors) of negative attitude variable were estimated and 4 indices can be seen in the following chart.

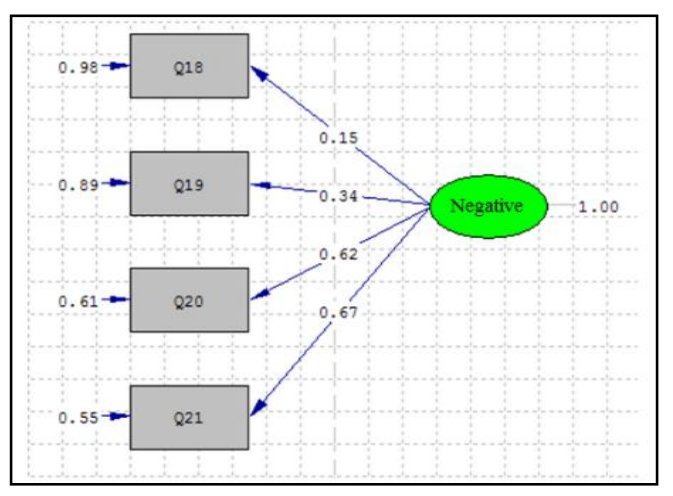

FIGURE 10. EVALUATING THE STANDARD FREQUENCY OF NEGATIVE ATTITUDE VARIABLE

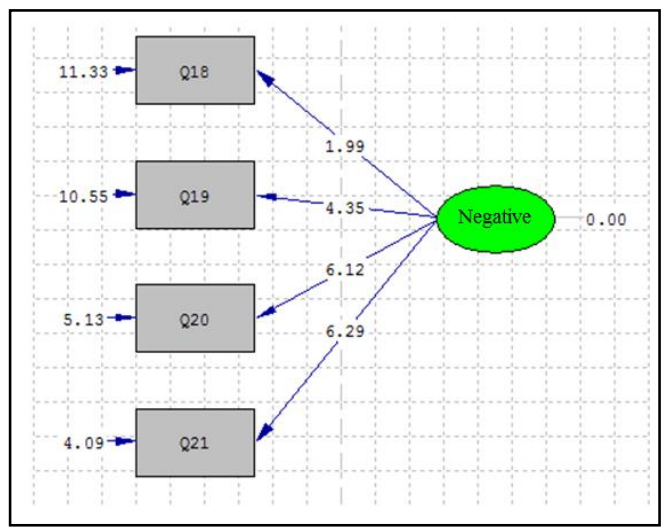

FiguRE 11. STUdENT-T TEST OF NEGATIVE ATTITUDE VARIABLE

TABLE IX. MULTIPLE DETERMINANT FACTORS FOR NEGATIVE ATTITUDE VARIABLE

\begin{tabular}{|c|c|c|c|c|}
\hline Negative attitude & $\begin{array}{l}\infty \\
\frac{x}{0} \\
\Xi\end{array}$ & 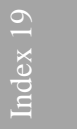 & 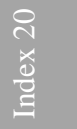 & 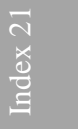 \\
\hline $\begin{array}{c}\text { Multiple } \\
\text { determinant } \\
\text { factors }\end{array}$ & 0.22 & 0.31 & 0.39 & 0.45 \\
\hline
\end{tabular}

Studying the indices of the model shows the validity of the model. Therefore, the final model can properly describe the relationship between the descriptive variables.

\section{F. Analyzing the positive attitude variable}

The following.

The standardized factors (standard regression factors) of positive attitude variable were estimated and 4 indices can be seen in the following chart. 


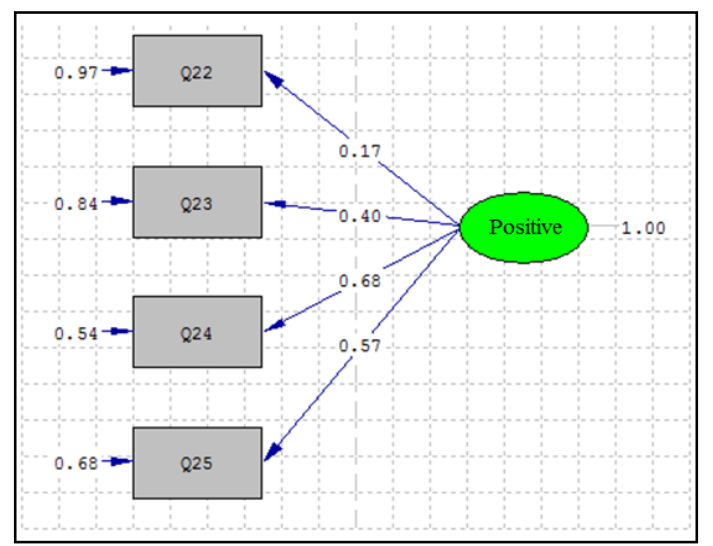

FIGURE 12. EVALUATING THE STANDARD FREQUENCY OF POSITIVE ATTITUDE VARIABLE

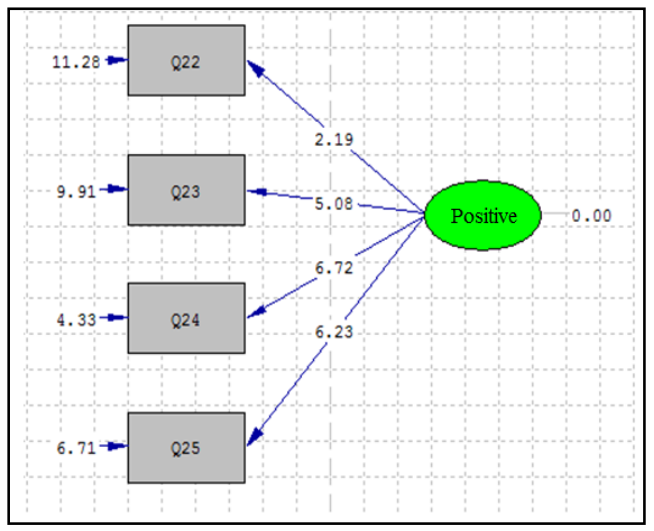

FiguRE 13. STUDENT-T TEST OF POSITIVE ATTITUDE VARIABLE

TABLE X. MULTIPLE DETERMINANT FACTORS FOR POSITIVE ATTITUDE VARIABLE

\begin{tabular}{|c|c|c|c|c|}
\hline Positive attitude & 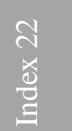 & 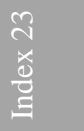 & 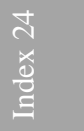 & $\begin{array}{l}\tilde{a} \\
\frac{u}{J} \\
\frac{o}{\Xi}\end{array}$ \\
\hline $\begin{array}{c}\text { Multiple } \\
\text { determinant } \\
\text { factors }\end{array}$ & 0.21 & 0.26 & 0.33 & 0.35 \\
\hline
\end{tabular}

Studying the indices of the model shows the validity of the model. Therefore, the final model can properly describe the relationship between the descriptive variables.

TABLE XI. DESCRIPTIVE STATISTICS

\begin{tabular}{|c|c|c|c|c|}
\hline Variables & Standard & RMSEA & p.value & Test result \\
\hline Ease of use & \multirow{4}{*}{ 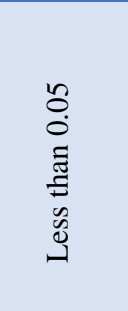 } & & & \\
\hline & & 0.001 & 0.50 & Accepted \\
\hline $\begin{array}{l}\text { Individual } \\
\text { knowledge }\end{array}$ & & 0.000 & 0.31 & Accepted \\
\hline $\begin{array}{l}\text { Mobile } \\
\text { technology }\end{array}$ & & 0.031 & 0.16 & Accepted \\
\hline
\end{tabular}

\begin{tabular}{|c|c|c|c|}
\hline $\begin{array}{l}\text { Negative } \\
\text { attitude }\end{array}$ & 0.000 & 0.25 & Accepted \\
\hline $\begin{array}{l}\text { Positive } \\
\text { attitude }\end{array}$ & 0.000 & 0.39 & Accepted \\
\hline
\end{tabular}

Studying the indices of the model shows the validity of the model. Therefore, the final model can properly describe the relationship between the descriptive variables.

\section{CONCLUSIONS}

In the following, we will explain the results of the research hypotheses.

Hypothesis 1: the results of this hypothesis is based on the results of the following research [17]

Hypothesis 2: the results of this hypothesis is based on the results of the following researches $[10,11]$.

Hypothesis 3: the results of this hypothesis is consistent with the results of the following research [8].

Hypothesis 4: the results of this hypothesis are consistent with the results of the following researches $[12,17]$.

Hypothesis 5: the results of this hypothesis are consistent with the results of the following researches $[5,9]$.

\section{REFERENCES}

[1] Al-Debei, M. M., \& Al-Lozi, E. (2014). Explaining and predicting the adoption intention of mobile data services: A value-based approach. Computers in Human Behavior, 35, 326-338.

[2] Andrews, M., Luo, X., Fang, Z., \& Ghose, A. (2015). Mobile ad effectiveness: Hyper-contextual targeting with crowdedness. Marketing Science, 35(2), 218-233.

[3] Corrocher, N., \& Lasio, L. (2013). Diversification strategies in network-based services: The case of mobile virtual network operators. Telecommunications Policy, 37(11), 1110-1123.

[4] Drossos, D., Giaglis, G. M., Lekakos, G., Kokkinaki, F., \& Stavraki, M. G. (2007). Determinants of effective SMS advertising: An experimental study. Journal of Interactive advertising, 7(2), 16-27.

[5] Friedrich, R., Gröne, F., Hölbling, K., \& Peterson, M. (2009). The march of mobile marketing: New chances for consumer companies, new opportunities for mobile operators. Journal of advertising research, 49(1), 54-61.

[6] Zandiyan S, Fotohi R, Koravand M. P-method: Improving AODV routing protocol for against network layer attacks in mobile Ad-Hoc networks. International Journal of Computer Science and Information Security. 2016 Jun 1;14(6):95.

[7] Jamali, S., \& Fotohi, R. (2017). DAWA: Defending against wormhole attack in MANETs by using fuzzy logic and artificial immune system. the Journal of Supercomputing, 73(12), 5173-5196.

8] Lodeiro-Santiago, M., Caballero-Gil, P., Aguasca-Colomo, R., \& Caballero-Gil, C. (2019). Secure UAV-Based System to Detect Small Boats Using Neural Networks. Complexity, 2019.

[9] Fotohi, R., Heydari, R., \& Jamali, S. (2016). A Hybrid routing method for mobile ad-hoc networks. Journal of Advances in Computer Research, 7(3), 93-103.

[10] Fotohi, R., \& Bari, S. F. (2020). A novel countermeasure technique to protect WSN against denial-of sleep attacks using firefly and Hopfield neural network (HNN) algorithms. The Journal of Supercomputing, 1-27.

[11] eMarketer. (2015). Mobile ad spend to top $\$ 100$ billion worldwide in $2016,51 \%$ of digital market. 
[12] Grewal, D., Bart, Y., Spann, M., \& Zubcsek, P. P. (2016). Mobile advertising: a framework and research agenda. Journal of Interactive Marketing, 34, 3-14.

[13] Kim, M. K., Park, M. C., \& Jeong, D. H. (2004). The effects of customer satisfaction and switching barrier on customer loyalty in Korean mobile telecommunication services. Telecommunications policy, 28(2), 145-159.

[14] Sarkohaki, F., Fotohi, R., \& Ashrafian, V. (2017). An efficient routing protocol in mobile ad-hoc networks by using artificial immune system. International Journal of Advanced Computer Science and Applications (IJACSA), 8 (4).

[15] Fotohi, R., Ebazadeh, Y., \& Geshlag, M. S. (2016). A new approach for improvement security against DoS attacks in vehicular ad-hoc network. International Journal of Advanced Computer Science and Applications, 7(7), 10-16.

[16] Behzad, S., Fotohi, R., Balov, J. H., \& Rabipour, M. J. (2018) An Artificial Immune Based Approach for Detection and Isolation Misbehavior Attacks in Wireless Networks. JCP, 13(6), 705-720.

[17] Mabodi, K., Yusefi, M., Zandiyan, S., Irankhah, L., \& Fotohi, R. Multi-level trust-based intelligence schema for securing of internet of things (IoT) against security threats using cryptographic authentication. The Journal of Supercomputing, $1-25$.

[18] Fotohi, R., Jamali, S., Sarkohaki, F., \& Behzad, S. (2013). An Improvement over AODV routing protocol by limiting visited hop count. International Journal of Information Technology and Computer Science (IJITCS), 5(9), 87-93.

[19] Leppäniemi, M., Sinisalo, J., \& Karjaluoto, H. (2006). A review of mobile marketing research. International Journal of Mobile Marketing, 1(1), 30-40.

[20] Li, Y. M., \& Yeh, Y. S. (2010). Increasing trust in mobile commerce through design aesthetics. Computers in Human Behavior, 26(4), 673-684.

[21] Megdadi, Y. A., \& Nusair, T. T. (2011). Shopping consumer attitudes toward mobile marketing: a case study among Jordanian user's. International Journal of Marketing Studies, $3(2), 53$.

[22] Okazaki, S., Katsukura, A., \& Nishiyama, M. (2006). Mobile context-advertised brand congruity: an experiment. In American Academy of Advertising. Conference. Proceedings (Online) (p. 57). American Academy of Advertising.

[23] Fotohi, R.; Nazemi, E. An Agent-Based Self-Protective Method to Secure Communication between UAVs in Unmanned Aerial Vehicle Networks. Preprints 2020, 2020010229 (doi: 10.20944/preprints202001.0229.v1).

[24] Behzad, S., Fotohi, R., \& Jamali, S. (2013). Improvement over the OLSR routing protocol in mobile Ad Hoc networks by eliminating the unnecessary loops. International Journal of Information Technology and Computer Science (IJITCS), 5(6), 2013.

[25] Behzad, S., Fotohi, R., \& Dadgar, F. (2015). Defense against the attacks of the black hole, gray hole and wormhole in MANETs based on RTT and PFT. International Journal of Computer Science and Network Solutions (IJCSNS), 3, 89103.

[26] Seyedi, B., \& Fotohi, R. NIASHPT: a novel intelligent agentbased strategy using hello packet table (HPT) function for trust Internet of Things. The Journal of Supercomputing, 1-24.

[27] Fotohi, R., Bari, S. F., \& Yusefi, M. (2019). Securing Wireless Sensor Networks Against Denial-of-Sleep Attacks Using RSA Cryptography Algorithm and Interlock Protocol. International Journal of Communication Systems.

[28] Okazaki, S. (2007). Lessons learned from i-mode: What makes consumers click wireless banner ads?. Computers in Human Behavior, 23(3), 1692-1719.

[29] Safeena, R., Date, H., Kammani, A., \& Hundewale, N. (2012). Technology adoption and Indian consumers: study on mobile banking. International Journal of Computer Theory and Engineering, 4(6), 1020.

[30] Ström, R., Vendel, M., \& Bredican, J. (2014). Mobile marketing: A literature review on its value for consumers and retailers. Journal of Retailing and Consumer Services, 21(6), 1001-1012.
[31] Fotohi, R., \& Jamali, S. (2014). A comprehensive study on defence against wormhole attack methods in mobile Ad hoc networks. International journal of Computer Science \& Network Solutions, 2, 37-56.

[32] Jamali, S., \& Fotohi, R. (2016). Defending against wormhole attack in MANET using an artificial immune system. New Review of Information Networking, 21(2), 79-100.

[33] Jamali, S., Fotohi, R., Analoui, M. (2018). An Artificial Immune System based Method for Defense against Wormhole Attack in Mobile Adhoc Networks. TABRIZ JOURNAL OF ELECTRICAL ENGINEERING, 47(4), 1407-1419

[34] Fotohi, R. (2020). Securing of Unmanned Aerial Systems (UAS) against security threats using human immune system. Reliability Engineering \& System Safety, 193, 106675.

[35] Sundararajan, P. (2002). Emerging Mobile Customer Relationship Management. Applications in Financial Services. EAI Journal, 44-47.

[36] Tsang, M. M., Ho, S. C., \& Liang, T. P. (2004). Consumer attitudes toward mobile advertising: An empirical study. International journal of electronic commerce, 8(3), 65-78.

[37] Ekström, K. M. (2007). Parental consumer learning or 'keeping up with the children'. Journal of Consumer Behaviour: An International Research Review, 6(4), 203-217.

[38] Yuan, S. T., \& Cheng, C. (2004). Ontology-based personalized couple clustering for heterogeneous product recommendation in mobile marketing. Expert systems with applications, 26(4), 461-476. 